\title{
Berlim na batucada (1944): proposições sobre o filme- revista no Brasil
}

\author{
Evandro Gianasi Vasconcellos \\ Mestrando em Imagem em Som pela \\ Universidade Federal de São Carlos, na \\ linha de pesquisa história e políticas do \\ audiovisual. Atualmente desenvolve \\ pesquisa sobre a relação entre cinema \\ e teatro de revista em filmes de Luiz de \\ Barros. \\ E-mail: evandrogianasi@gmail.com
}

Resumo: Este artigo objetiva discutir a continuidade de um filão cinematográfico que tem como relação imediata aspectos da linguagem do teatro de revista, um tipo de entretenimento de grande sucesso no Brasil no final do século XIX e primeira metade do século XX. A partir da análise do filme Berlim na batucada (Luiz de Barros, 1944), pretende-se demonstrar o diálogo entre cinema e teatro de revista nas comédias musicais dos anos 1940. Observando também, através de uma breve revisão, que essa relação já se fazia presente na produção nacional desde a primeira década do século passado, com os cantantes da chamada "Bela época", tendo como destaque o filme Paz e amor (Alberto Moreira, 1910).

Palavras-chave: cinema brasileiro; teatro de revista; filme-revista; Berlim na batucada.

Abstract: This article aims to discuss the continuity of a cinematographic vein that is closely related to aspects of the "teatro de revista" (musical revue) language, a successful type of entertainment in Brazil in the late nineteenth century and in the first half of the twentieth century. Based on the analysis of the movie Berlim na batucada (Luiz de Barros, 1944), we intend to demonstrate the dialogue between cinema and "teatro de revista" in the musical comedies of the 1940s. Observing also, from a brief historical overview, how this relation was already present in the Brazilian film production since the first decade of the last century, with the "cantantes" of the "Bela época", highlighting the movie Paz e amor (Alberto Moreira, 1910).

Keywords: Brazilian cinema; musical revue; "filme-revista"; Berlim na batucada.

Uma constante dentro da produção cinematográfica brasileira durante as décadas de 1930 e 40 foram os filmes musicais realizados por produtoras como a Cinédia, a Sonofilmes ou a Atlântida, esta última atingiria seu apogeu com as clássicas chanchadas, sobretudo, na década de 1950. Em sua grande maioria, os filmes musicais eram produções feitas com poucos recursos em ocasião do carnaval, com o intuito de lançar ou divulgar as marchinhas e canções do ano e, baseados em um enredo simples e bem humorado, desfilar quadros musicais com os mais conhecidos cantores do rádio e dos palcos.

Berlim na batucada, um exemplo clássico desse formato, foi o musical da Cinédia para o carnaval de 1944. Depreciado pela crítica, o filme dirigido por Luiz de Barros é acusado, por ela, de precariedade estética em relação a aspectos técnicos e de uma suposta falta de articulação no enredo. No entanto, acreditamos ser necessária a abordagem do filme por um ângulo diferente, observando o modo como se relaciona com outra forma de entretenimento, até então de grande repercussão entre um público mais popular: o teatro de revista. 
A proposta deste artigo é observar como o filme Berlim na batucada se enquadraria dentro de uma tendência recorrente no cinema brasileiro em realizar filmes que, de algum modo, se apropriam de elementos do teatro de revista em sua construção. Para isso, utilizaremos a concepção metodológica indicada por Jean-Claude Bernardet, de trabalhar com "filões" em que determinado corpus de filmes relaciona-se de maneira independente de uma visão cronológica, estabelecendo assim um esboço para se pensar em uma classificação genérica de filme-revista, assim denominado nos estudos sobre gênero realizados por Rafael de Luna Freire. Por último, detenhome em uma análise do filme em questão, apontando elementos e aspectos comuns ao teatro de revista, incorporados em sua construção.

\section{Berlim na batucada: uma comédia carnavalesca}

O cinema brasileiro, através de sua história, sempre se viu diante da dificuldade em se firmar em um mercado tomado pelo cinema estrangeiro, mais especificamente o norte-americano. $O$ fato de terem existido esforços para se estabelecer uma produção regular, tendo em mente um ideal de industrialização do cinema produzido no país, é de grande importância na história do cinema brasileiro. Adhemar Gonzaga foi uma das figuras que mais lutou por uma consolidação do filme brasileiro no mercado e para isso criou a produtora Cinédia, investindo na construção de um estúdio equipado e pronto para realizar filmes. A Cinédia manteria uma produção constante nas décadas de 1930 e 40, com títulos que se alternavam entre os ditos filmes "sérios" e as comédias, estas últimas feitas geralmente com menor orçamento, em menos tempo e com a promessa de grande público nos cinemas.

Um dos diretores que mais filmou para a Cinédia foi Luiz de Barros. Com uma carreira cinematográfica ativa desde a década de 1910, Lulu (como era conhecido) é uma figura singular no cinema brasileiro, tendo dirigido filmes em momentos extremamente difíceis para a produção nacional, quase sempre com exibição garantida nas salas de cinema. $\mathrm{Na}$ Cinédia, fez várias comédias, além de outros gêneros; porém, frequentemente era massacrado pela crítica, que rejeitava seus filmes, realizados geralmente às pressas e de maneira precária. Eram as comédias musicais carnavalescas, já esperadas pelo público nessa época do ano e garantia de boa bilheteria. Com isso, aliado à política de baixos custos de produção e rapidez na realização, esses filmes contribuíam para assegurar a sobrevivência da produtora carioca.

Berlim na batucada foi um dos filmes feitos por Luiz de Barros para a Cinédia e lançado pouco antes do carnaval de 1944. Recheado de artistas conhecidos do grande público, o filme era a aposta da Cinédia para gerar boas receitas em um ano muito complicado devido ao curso da Segunda Guerra Mundial, que dificultava a importação de filme virgem. Nada mais propício do que, então, um filme que aproveitava o sucesso de atores dos palcos, como Procópio Ferreira, Delorges Caminha e a dupla Lyson Gaster e Alfredo Viviani, e, também dos músicos do rádio e teatro de revista, como o Trio de Ouro, Francisco Alves, Leo albano, Alvarenga e Ranchinho, Trigêmeos Vocalistas, entre outros.

Nos jornais, houve intensa publicidade por meio de anúncios e notas sobre o filme, sempre ressaltando o elenco com grandes estrelas. O jornal $A$ Manhã, do Rio de Janeiro, em uma dessas notas publicitárias escreveu: "para mostrar quanto vale 'Berlim na batucada' basta declinar o nome de todos os artistas - as figuras mais famosas e populares do nosso 'broadcasting', cinema e teatro" (A Manhã, 6 fev 1944: 5), seguido de uma extensa lista com todos os nomes.

Essa proposta de divulgação estava em sintonia com o ideal de Gonzaga a respeito do star system. A Manhã, por exemplo, passou a publicar diariamente, a partir de 30 de janeiro até 6 de fevereiro, dia anterior à estreia, notas que destacavam alguma atração do elenco do filme, sempre ilustradas com fotos. Além disso, os anúncios dos cinemas eram preenchidos com o nome dos astros presentes no filme. 
Outra abordagem da publicidade era a ligação com a temática carnavalesca, uma vez que esse tipo de filme já era aguardado pelo público, destacando assim a sua parte musical:

Em "Berlim na batucada" há ainda a mais preciosa coletânea de sambas, marchas e canções que se pode imaginar e que por si só seria suficiente para garantir o êxito integral desse soberbo espetáculo que todo o Rio de Janeiro vai - a partir de amanhã - admirar e aplaudir (A Manhã, 6 fev 1944: 5).

No entanto, os ataques ao filme na imprensa foram ferrenhos. Pedro Lima escreveu para o jornal carioca Diário da Noite uma crítica que demonstra o descontentamento dos críticos com esse tipo de filme.

\begin{abstract}
"Berlim na batucada" é um caso típico de decadência. O filme não tem cenário, não tem fotografia, não tem som, não tem nada, nem mesmo vislumbre de direção. [...] Com outro trabalho semelhante ninguém mais acreditará na possibilidade de que possamos fazer filmes. E o que mais admira é que sejam exibidas estas realizações apressadas que só vão contrariar toda a boa vontade do governo de amparar e desenvolver um cinema nosso, tão útil quanto necessário (Diário da Noite, 11 fev 1944: 5).
\end{abstract}

Na mesma crítica, Pedro Lima ainda cita negativamente o filme Abacaxi azul (Wallace Downey, 1944), da Sonofilmes, filme carnavalesco lançado pouco antes, no mesmo ano, que ainda teria o filme da Atlântida, Tristezas não pagam dívidas (Ruy Costa, 1944), lançado com o mesmo propósito. No entanto, uma matéria não assinada do jornal $A$ Noite, em ocasião do lançamento desses três filmes, enxerga a questão sob outro ângulo: "Pelo que se vê, a indústria cinematográfica brasileira tem, na época do carnaval, um grande estímulo para o seu desenvolvimento" (A Noite, 4 fev 1944: 9).

Porém, grande parte da crítica da época via nesses filmes problemas em relação a sua concepção, baseando-se em uma ideia de que o cinema clássico americano seria o exemplo a ser seguido, algo de que os musicais carnavalescos nitidamente se distanciavam em alguns aspectos. A forma de análise deveria seguir outro caminho, que Arthur Autran notaria ao escrever sobre o filme Berlim na batucada para o catálogo da mostra Cinédia 75 anos, realizada em 2006:

Evidentemente na análise deste filme não cabe colocá-lo em perspectiva do ideal hollywoodiano de fluidez narrativa. Ele tem mais relação com o teatro de revista e o seu formato de quadros, apenas ligados de forma tênue pelo laço da trama, de maneira a facilitar a inserção dos números musicais que constituem boa parte da fita (AUTRAN, 2006).

Ao visualizar o filme de Luiz de Barros, é nítida a relação com o formato do teatro de revista, perceptível principalmente através de sua estrutura em quadros, mas também por diversos elementos comuns ao gênero. Como referência para as regras e convenções seguidas normalmente nas revistas, temos o trabalho de Neyde Veneziano, $O$ teatro de revista no Brasil, livro originado de sua tese. A partir desse estudo, poderemos observar características que se fazem presentes, também, na obra cinematográfica.

Primeiramente, é necessário destacar a preocupação já existente no pensamento de Jean-Claude Bernardet, no livro Historiografia clássica do cinema brasileiro, com as pesquisas que tendem a se limitar a "fazer a articulação entre a nossa área de atuação, o cinema, e um estudo referente a uma outra área que desconhecemos" (BERNARDET, 1995: 103). Bernardet considera esse um "primeiro passo", que deverá ser seguido da própria pesquisa do historiador na outra área de interesse. A presente pesquisa sobre o teatro de revista e seus reflexos em filmes de Luiz de 
Barros ainda é um trabalho em andamento e que será melhor desenvolvido após o ato de "ir às fontes". Porém, a leitura de obras mais abrangentes sobre o teatro de revista já nos permite algumas observações importantes em relação à Berlim na batucada, que exploraremos mais adiante.

\section{A trajetória do filme-revista no Brasil}

Jean-Claude Bernardet realiza uma interessante discussão metodológica ao questionar a "historiografia clássica", baseada nos estudos panorâmicos de Alex Viany e Paulo Emilio Salles Gomes, rejeitando a ideia de ciclos, que se iniciam e terminam, para pensar a história do cinema no país. $\mathrm{O}$ autor se pergunta:

Não deveríamos rechaçar o corte cronológico vertical, e trabalhar horizontalmente com filões que apresentariam ritmos diferenciados e tentar estabelecer entre eles relações, sem querer encaixá-los em unidades temporais consideradas válidas para todos os filões? (BERNARDET, 1995: 59).

Deste modo, desconsiderando o corte temporal que insere os cantantes e os filmes-revista exibidos no final da primeira década do século XX, dentro da chamada "bela época", podemos pensar em uma "linha de coerência" que desenhe uma trajetória em que filmes como Paz e amor (Alberto Moreira, 1910) e Berlim na batucada (Luiz de Barros, 1944) sejam reconhecidos como pertencentes a um mesmo filão cinematográfico.

Rafael de Luna Freire, ao abordar "os gêneros do cinema brasileiro sonoro nos anos 1930" (FREIRE, 2011: 233), faz uma análise interessante do que ele chamará de filme-revista, voltando até o período da "bela época", com os cantantes, para então abordar a realização de filmes durante a década de 1930, que se enquadrariam no gênero, inclusive aqueles produzidos pela Cinédia.

A partir de 1908, popularizou-se no Brasil um tipo de filme que seria conhecido por cantante. Nas palavras de Fernando Morais da Costa, "musicais de curta duração dublados na hora da exibição pelos atores posicionados atrás da tela" (COSTA, 2006: 40). Fenômeno que tem sua origem incerta, esse tipo de filme passou a ser explorado por realizadores do país e alcançou grande repercussão no público de cinema, que ainda começava a se formar.

O desejo de abastecer as imagens cinematográficas com o artifício do som sincronizado já existia desde os primórdios do cinema, como aponta Costa em sua tese. Com isso, o investimento nesse tipo de atração, os cantantes, iniciado em 1908, consolidou-se na produção do ano seguinte.

Fernando Morais da Costa rebate a hipótese de Bernardet de que não se poderia afirmar que a maioria dos filmes cantantes exibidos eram brasileiros. Através de dados, demonstra que a produção de William Auler, proprietário do cinema Rio Branco, era majoritária. Algumas outras salas também investiriam na exibição dos cantantes, tanto importados quanto produções próprias, até o ano de 1911, onde esse tipo de filme entraria em declínio e não mais encontraria espaço nos cinemas.

Geralmente os filmes apresentavam a reprodução de árias de óperas. Porém, dentro desse período de produção dos cantantes, outro gênero de filme se constituiu na cinematografia brasileira: o filme-revista.

Em abril de 1910, a Empresa William \& Cia, de Auler, estreia no cinema Rio Branco o filme Paz e Amor, com direção de Alberto Moreira e fotografado por Alberto Botelho. Os anúncios reproduzidos por Vicente de Paula Araújo em sua pesquisa demonstram a ligação com o gênero teatral: "Revista Paz e Amor, gênero que é, pela primeira vez no mundo, explorado em cinematógrafo" (ARAÚJO, 1976: 331). O 
sucesso do filme parece evidente a partir da informação da ocorrência de mais de mil exibições do filme, como afirma José Inácio de Melo Souza (SOUZA, 2004).

Paz e Amor possui uma referência clara à revista de ano, presente na estrutura, "4 partes, 5 quadros e 2 apoteoses" (ARAúJO, 1976: 332), na temática de sátira política e crítica de costumes e nos personagens caricaturais. Além disso, foi escrita por José do Patrocínio Filho, com o pseudônimo de Antônio Simples, famoso por suas revistas, e musicado por Costa Junior, que também trabalhava nos palcos do teatro de revista.

O filme tem intensa repercussão e, com isso, se sucedem a ele outras produções que também se utilizarão do sucesso do gênero nos palcos para atrair público para os cinemas. Os filmes O cometa (1910), O Chantecler (1910), O Rio por um óculo (1910) e 606 (1910) são exemplos de produções brasileiras anunciadas como revistas cinematográficas no mesmo ano e que possuíam estrutura semelhante às peças, além do trânsito de autores e artistas com carreira no teatro.

Jean-Claude Bernardet observa que esses filmes, embora possuíssem características das revistas de ano, não utilizavam esse nome como publicidade, preferindo "revista de costumes" ou apenas "revista". O autor coloca como hipótese para isso a perda de espaço que esse tipo de espetáculo, que se propunha a uma revisão dos principais acontecimentos do ano, enfrentava, a ponto de em 1907 não mais encontrar palcos para serem apresentados. O que justificaria o interesse momentâneo nesse gênero de filme não ter se firmado. "Dependentes de um sucesso antigo e sem renovar o gênero pelo cinema, os cineastas teriam sido incapazes de consolidar a produção cinematográfica brasileira junto a seu público" (BERNARDET, 1995: 102).

Sobre o "fim" dos cantantes existe um mito criado por autores da historiografia clássica, como Paulo Emilio Salles e Alex Viany, que tendem a apontar fatores externos como elemento causador de uma quebra na produção brasileira, como a estabilização das distribuidoras de filmes estrangeiros no país. Porém, Bernardet (1995) chama a atenção para a necessidade de estudar, também, os fatores internos para essa queda brusca no número de filmes realizados no Brasil, associando a falta de estudos a partir desse viés como resultado de um "'complexo de vítima' muito entranhado em parte da intelectualidade brasileira" (BERNARDET, 1995: 108).

Seguindo esse caminho, Souza apontará outras razões para explicar essa interrupção na produção, observando que um produto cinematográfico restrito a poucas salas, principalmente o cinema Rio Branco, e que não seria totalmente reprodutível na cadeia exibidora, não conseguiu se estabelecer. Com isso, podese localizar "nas limitações do produto fabricado os problemas de permanência como prática cinematográfica" (SOUZA, 2004: 292). Para o autor:

Ao mesclar a aura e a reprodutibilidade, pensando-se nos termos de Walter Benjamin, o objeto único e a repetição, o espetáculo teatral do século XIX com o cinema do século $X X$, notamos claramente a armadilha em que se meteu o sistema produtivo do Rio Branco (SOUZA, 2004: 292).

Desta forma, pode-se compreender como plausível o argumento de José Inácio de Melo Souza, que percebe uma desarticulação do principal produtor de cantantes, ligado ao Rio Branco. O autor nota que após um incêndio em 1910, o Rio Branco passa por uma itinerância provisória e reabre em 1911 como cineteatro, dividindo as atenções com a montagem de revistas teatrais.

O fato é que, ao observarmos o estudo de Fernando Morais da Costa, que pretende traçar a história do som no cinema brasileiro, percebemos praticamente um salto no tempo, que vai do fim dos cantantes para a passagem definitiva para o cinema sonoro, na segunda metade da década de 1920. Com exceção de algumas 
experiências, como as de Paulo Benedetti e os acompanhamentos musicais por orquestras, pouco se explorou em termos de sincronização nesse intervalo de tempo, no cinema brasileiro.

De fato, os estudos do cinema brasileiro deste período, as décadas de 1910 e 1920, esbarram na inexistência de cópias de grande parte da produção, impedindo a análise dos filmes; desta forma, fica difícil saber sobre a existência de aspectos do teatro de revista em filmes mudos produzidos nesse intervalo.

No entanto, podemos encontrar informações sobre um filme como A Capital Federal (1923), dirigido por Luiz de Barros. O filme era uma adaptação da peça teatral homônima de Artur Azevedo, com texto originado do fio condutor da revista de ano o Tribofe, do mesmo autor. Por sua temática, o longa-metragem também lembra o enredo das revistas de ano: uma família do interior que vai à Capital Federal e se depara com os aspectos e modo de vida próprio da cidade grande.

Após a Primeira Guerra Mundial, o teatro de revista vivenciaria intensas mudanças, abandonando de vez o antigo modelo em favor de novos tipos de espetáculos. Neyde Veneziano afirma que: "sem receber influências do estrangeiro, cada vez mais a revista se nacionalizava. E é nesse processo de abrasileiramento que a sua ligação com a música popular torna-se mais inevitável, estreita e indissolúvel" (VENEZIANO 1991: 41, grifo do original). Com esse novo modelo, a música foi adquirindo maior espaço em detrimento do fio narrativo, que cada vez mais ia se atenuando. Antunes destaca que a partir da década de 1920:

O teatro ligeiro embarcava na folia, considerava-se definitivamente o grande período das revistas-carnavalescas, que impulsionou a popularidade do gênero. As peças, realizadas durante os meses que antecediam o Carnaval, lançavam as músicas que iriam animar a festa.

Os autores das marchas disputavam as melhores companhias para lançar suas novas composições. Se a música fosse bem recebida nos palcos da Praça Tiradentes, logo começaria a ser cantarolada pelas ruas da cidade, estendendose posteriormente para todas as regiões do país (ANTUNES, 2002: 49-50).

Podemos colocar como hipótese que o cinema das décadas de 1910 e 1920, predominantemente mudo, já tendo ultrapassado, há muito, o período dos cantantes, teria grandes dificuldades em se apropriar dessa nova forma de revista, pautada na música. No entanto, com a chegada do som ao cinema, de forma mecânica e definitiva, foi possível incorporar com maior facilidade a revista teatral dentro do produto cinematográfico. Temos então um reaquecimento do gênero, agora longe do modelo da revista de ano e mais em sintonia com o gênero contemporâneo de sucesso nos palcos.

Faz-se necessário levar em consideração que a revista como gênero cinematográfico não era um fenômeno próprio do cinema brasileiro, muito pelo contrário. Nos primeiros anos do filme "falado" proliferavam as revistas musicais hollywoodianas exibidas no país. Freire comenta que:

Na chegada do Vitaphone e do Movietone ao Brasil, a voz e o canto dos astros e estrelas eram as maiores novidades de sucessos como Melodia da Broadway (The Broadway Melody [dir. Harry Beaumont, 1929]) ou Movietone-Follies (Fox Movietone Follies of 1929 [dir. David Butler, 1929]) (FREIRE, 2011: 235).

Os filmes eram denominados, pela publicidade, de revistas e se utilizavam da estrutura de quadros musicados, abusando de cenários luxuosos e de grandes elencos. Rafael de Luna Freire (2011) ressalta que "o gênero 'revista' permanecia claro e codificado no Brasil ao ponto de ser usado como uma das categorias 
genéricas nas classificações estatísticas de obras cinematográficas do IBGE ao longo da década de 1930" (FREIRE, 2011: 240).

Esses filmes também eram muito criticados por parte da imprensa, devido ao seu distanciamento em relação ao que julgavam ser a arte do cinema. É curiosa a citação feita por Costa (2006) de um trecho da crítica de Almir Castro, no periódico O fan:

Protesto contra todos aqueles que ao sair de Broadway Melody disseram muito pasmadamente que não iriam mais aos filmes mudos (...) sim, por que Broadway Melody diverte. Eu me diverti vendo o filme, do mesmo modo que poderia me distrair vendo a última revista de Aracy Cortes" (apud, COSTA, 2006: 86).

O colunista referia-se a uma atriz que fez grande fama por sua atuação no teatro de revista.

Em 1929, aproveitando o momento de empolgação com o filme sonoro, Luiz de Barros realiza a comédia Acabaram-se os otários. Aqui, é importante fazer um parêntese para lembrar que Lulu havia, anos antes, interrompido sua carreira como cineasta para se dedicar ao teatro de revista, em que teve importante papel como diretor artístico e cenógrafo. Entre seus trabalhos no teatro, fez parte da companhia Tro-lo-ló do célebre Jardel Jércolis, e montou a Companhia Ra-ta-plan. Luiz de Barros conta, em sua autobiografia, também ter montado um "teatrinho de variedades" em um salão do Cine-teatro Santa Helena, onde os protagonistas seriam Tom Bill e Genésio Arruda. Trata-se do Moulin Bleu, inaugurado no dia 11 de agosto de 1928 no salão Egípcio, na parte inferior do prédio Santa Helena, localizado na Sé, em São Paulo.

A mesma dupla protagonizaria o filme Acabaram-se os otários, o primeiro realizado pela produtora Sincrocinex, criada pelo próprio Luiz de Barros com o intuito de realizar filmes sonoros, algo ainda pouco explorado no país até aquele momento. O filme possui um enredo que, novamente, lembra os antigos fios condutores das revistas de ano, além de se assemelhar muito ao tema de uma revista de sucesso encenada no Teatro Recreio em julho do mesmo ano, Compra um bonde, de Carlos Bitencourt, Cardoso de Menezes e Alfredo de Carvalho. Sobre a revista, Paiva comenta:

Mais bem humorada do que luxuosa, mesclava a charge política com a sátira de costumes. Baseava-se no episódio de um filho de Minas Gerais que fora vítima, no Rio, de um conto do vigário; a ilação, para uma plateia alegre, era de que todos os mineiros eram bobos (PAIVA, 1991: 321, grifo do original).

Porém, Acabaram-se os otários não se vendeu como uma revista cinematográfica. Já o filme Coisas nossas (1931), de Wallace Downey, lançado pouco depois, possuiria elementos mais identificáveis com o gênero teatral que, então, vivia um momento de apogeu com a revista em sua forma mais musical. Através da descrição feita por Fernando Morais da Costa, a partir da audição da faixa sonora do filme, único material existente do filme desaparecido, podemos perceber uma estrutura com vários números musicais e esquetes rápidas que não chegam a formar um enredo articulado.

O filme foi divulgado, à época de seu lançamento, como uma "revista nacional", em consonância com um gênero estabelecido naquele momento. Freire comenta que:

No início do cinema sonoro no Brasil, diante das referências culturais específicas dos críticos, a recepção aos então chamados "filmes-revistas" ou "revistas de tela" (com)fundia a revista cinematográfica com o musical de bastidores, nivelando qualquer filme, brasileiro ou estrangeiro, em que as canções e os 
números musicais tivessem um papel preponderante na narrativa, fosse o produto mais popular de Luiz de Barros, fosse o pretensamente mais sofisticado de Downey (FREIRE, 2011: 237).

A Cinédia realizou seu primeiro filme carnavalesco em 1933, A voz do carnaval (Adhemar Gonzaga e Humberto Mauro). Começava, então, uma aproximação com os gêneros mais populares. A produtora passaria a investir em comédias musicais com a utilização de músicos conhecidos do público e artistas cômicos, muitos oriundos do teatro. Devemos salientar que o momento de grande difusão do rádio e da música popular, veiculada por ele, constituiu-se em um apreço do público por determinados nomes que, ao figurar nos filmes, eram atrações consideráveis de audiência.

A relação com o teatro de revista apareceria de maneira mais evidente em filmes como Alô, Alô, Carnaval (1936), dirigido por Adhemar Gonzaga, embora algumas fontes creditem também o nome de Wallace Downey. Rafael de Luna Freire observa a estrutura do filme:

Como um auto-intitulado "filme-revista", o longa-metragem narrava as desventuras de dois autores pobretões (Barbosa Junior e Pinto Filho) para conseguir montar a revista Banana da terra no luxuoso Cassino Mosca Azul. Ou seja, descrevia em forma de comédia o processo de levar a revista à cena. Mas paralelamente a esse fio de história sobre os bastidores da montagem do espetáculo, eram encenados desde o início do filme, como uma revista filmada (e sob a influência do rádio e do disco), diversos números de astros da música brasileira nos palcos do tal cassino (FREIRE, 2011: 243, grifo do original).

\section{Berlim na batucada como um filme-revista}

Luiz de Barros chega à Cinédia dirigindo uma coprodução, o filme Carioca maravilhosa (1935). O diretor segue realizando algumas comédias pela produtora de Gonzaga, algumas adaptações de peças, e também filmes carnavalescos, como Tereré não resolve! (1938), filme que embora contenha poucos números musicais tem um enredo que se passa na época de Momo.

Na década de 1940, Lulu teria a oportunidade de fazer filmes que são bem próximos a uma ideia de filme-revista, como Samba em Berlim (1943), Berlim na batucada (1944) e Caídos do céu (1946), entre outros. São títulos que possuem uma grande quantidade de números musicais e características que contribuem para que possamos enquadrá-los no mesmo filão dos filmes citados anteriormente.

Berlim na batucada tem como enredo as peripécias do malandro Mexerica (Procópio Ferreira) que, por engano, recebe a missão de recepcionar um produtor americano (Delorges Caminha), já que a pessoa destinada a acompanhá-lo pelo Rio de Janeiro toma um porre e fica de cama. O produtor deseja encontrar artistas brasileiros para um filme nos Estados Unidos, porém, o malandro o desvia de seu roteiro original, levando-o, primeiro, a uma pensão barata. Ao invés do Palace Hotel, hospeda-o na "Pensão Palácio". O americano acabará por conhecer os artistas do morro: o maioral Chico (Francisco Alves), sambista e defensor do morro, que está ameaçado de ser derrubado; a mulata Odete (Solange França) namorada de Chico, mas cobiçada por Mexerica; a escola de samba, entre outros cantores. São esses artistas que o produtor estrangeiro levará para Hollywood, apesar da dificuldade em convencer Chico a sair da favela, mas que acaba convencido por causa de Odete, e mostrará à "América o verdadeiro samba".

O enredo é bastante fragmentado durante o filme por meio de vários elementos. O mais evidente são os cantores que apresentam números musicais, pois, embora sejam geralmente justificados, sendo assistidos por algum personagem, não 
possuem uma conexão clara com a história principal. Algumas músicas tornaramse grandes sucessos no carnaval do ano de 1944, como "Odete", de Herivelto Martins e Dunga, cantado por Leo Albano e "Verão no Havaí", de Benedito Lacerda e Haroldo Lobo, interpretado por Fada Santoro e dublado por Dalva de Oliveira. Deste modo, o filme cumpria sua função, assim como as revistas carnavalescas, de divulgar as canções populares e os principais artistas do rádio.

Outro elemento de quebra são as cenas que não fazem avançar a trama principal, e, embora sejam representadas por personagens em torno dos dois protagonistas, configuram-se mais como esquetes cômicos, típicos do teatro de revista. Como exemplo, podemos citar o sonho do assistente do americano (Chocolate), um esquete satirizando Hitler, interpretado por Ivo de Freitas, que, inclusive, é a única referência, afora o título, ao conflito mundial. Na cena, Hitler lamenta a situação do Eixo e é ridicularizado, "o maior palhaço do mundo". Sátiras ao ditador durante os anos da Grande Guerra podem ser encontradas, também, nas revistas teatrais do período. Um exemplo é a revista de grande sucesso da Companhia de Walter Pinto, Fora do Eixo, escrita por Freire Jr. e Luís Iglésias, estreada em 27 de fevereiro de 1942 no Teatro Recreio. Em um dos esquetes, Silva Filho e Manuel Vieira interpretavam, respectivamente, Hitler e Mussolini, de maneira caricatural, satirizando os ditadores e "provocando um dilúvio de gargalhadas" (PAIVA, 1991: 482).

Outra cena, com a mesma característica de esquete é o romance entre a filha do dono da pensão (Luizinha Carvalho) e um sambista (Leo Albano), que não tem maiores consequências para a trama do que apresentar uma discussão de família sobre a discriminação do músico popular, chamado de vagabundo, explorando toda a comicidade de Mathilde Costa e Manoel Rocha, que no filme interpretam os pais da jovem.

O papel desempenhado por Príncipe Maluco, nome artístico adotado pelo comediante João Petrillo, é o mais curioso dentro do filme. Com duas aparições, o ator cômico "interrompe" o filme, dirigindo-se diretamente ao espectador. A primeira ocorre logo após os créditos iniciais, em que o ator apresenta o filme, avisando que é nacional: "Uma fitinha dessas às vezes agrada", "o cinema nacional tá muito melhorado". Discurso que aparece como provável consequência dos ataques contra os filmes populares brasileiros.

A segunda aparição remete mais nitidamente aos tradicionais números de cortina das revistas. Príncipe Maluco entra após um número musical com muitos figurantes e uma escola de samba. Com um violão, o ator conta piadas e toca trechos de músicas até ser expulso de cena novamente, para a continuação do filme. No teatro, esse tipo de número ocorria com o objetivo de divertir o público, geralmente com um comediante talentoso, mas também para preencher o tempo enquanto se mudava o cenário para a próxima cena. Veneziano afirma que:

a maioria deles [dos números de cortina] consistia num pequeno quadro cômico que, sem depender de cenário, poderia caber em qualquer revista, pois não obedecia a nenhuma regra pré-estabelecida e funcionava apenas para fazer rir e esperar o tempo passar (VENEZIANO, 1991: 100).

Deste modo, a utilização de tal quadro no filme, que não necessitaria dessa pausa, parece tratar-se apenas de uma referência ao teatro de revista, no qual, inclusive, o ator Príncipe Maluco atuou em grande parte de sua carreira artística. Veneziano comenta, também, sobre os números de cortina com duplas sertanejas, que elas faziam "um número misto de músicas e piadas, explorando o desafio, o humor non-sense, o trocadilho e as adivinhações" (VENEZIANO, 1991: 101), algo muito semelhante ao que ocorre no filme, embora o ator atue sozinho, dirigindose diretamente ao público. Assemelha-se também ao tipo de número citado por Veneziano a interpretação da dupla sertaneja Alvarenga e Ranchinho, com a 
música "Mizerave"; nele, os cantores estão em um palco cantando, interagindo com uma plateia dentro do filme e interrompendo a canção para fazer piadas e discutir sobre a música. Um tipo de apresentação que eles já faziam no Cassino da Urca, no rádio e no próprio de teatro de revista.

Chama a atenção no filme ainda a construção do personagem Mexerica, que remete ao malandro carioca, personagem-tipo constante no teatro de revista. No filme, faz de tudo para se dar bem sem precisar trabalhar, e no final consegue ir para Hollywood e sair do morro, sua ambição. Veneziano observa que "no sistema moral das revistas, as malandragens, os trambiques, as marmeladas e os pequenos golpes nunca eram punidos. No final, tudo era resolvido com o jeitinho brasileiro" (VENEZIANO, 1991: 124, grifo do original).

Outra característica que podemos aproximar do teatro de revista é a crítica social. No filme, ela aparece através de músicas que refletem sobre a mudança dos espaços públicos no Rio de Janeiro. Com Bom dia, Avenida, executada pelo Trio de Ouro, composto por Dalva de Oliveira, Herivelto Martins e Nilo Chagas, critica-se a destruição de praças e ruas, para a abertura de largas avenidas. A canção Silenciar a Mangueira, não, interpretada pelo personagem Chico (Francisco Alves), é um manifesto contra a ameaça de colocar o morro abaixo. Transformações que ocorriam em um processo de urbanização que acabou culminando no desaparecimento de importantes cenários da cultura popular. Suzana Ferreira (2006) comenta que:

Chico estava preocupado com o destino não apenas daquele morro, mas preocupava-se com os redutos da cultura popular que estavam sendo outra vez postos abaixo na década de 40 , sempre com a finalidade de, cada vez mais, abrir corredores espaçosos para as mercadorias, para o fluxo acelerado do automóvel, do transporte coletivo, das relações econômicas. O tempo se acelerava, os morros estavam no caminho, era preciso removê-los (FERREIRA, 2006: 159).

O tom crítico é leve e, com as marchas carnavalescas de Herivelto Martins, refletem um problema vivido pela cidade. $O$ período não permitia maiores críticas políticas, e mesmo o teatro de revista pouco arriscava nessa direção por medo da censura do Estado Novo.

\section{Considerações finais}

Rafael de Luna Freire, ao falar sobre o filme-revista, destaca o desprestígio do gênero cinematográfico, principalmente, em relação aos filmes do final da década de 1930, acusados de não serem verdadeiramente cinema. Com isso, até mesmo os filmes americanos, considerados superiores, evitariam tal rótulo: "sob essa ótica, o termo 'filme-revista', com sua filiação teatral, seria progressivamente desvalorizado, sendo evitado na descrição de filmes musicados considerados mais 'autenticamente' cinematográficos”' (FREIRE, 2011: 244).

Desta forma, poderíamos compreender o fato de Berlim na batucada ter evitado enfatizar essa relação em sua publicidade, embora, a partir das observações a respeito do filme, sejam perceptíveis as semelhanças com a ideia da revista teatral, principalmente a carnavalesca. No entanto, existe outra hipótese para tentar explicar essa postura de negação do teatro de revista, que se levanta a partir do pensamento de Bernardet em torno da rejeição ao termo "revista de ano" para qualificar filmes como Paz e Amor.

Ao observarmos a trajetória do teatro de revista no Brasil, o início da década de 1940 configura-se como de mudanças significativas na estrutura e no público desse espetáculo. As revistas abandonavam o enredo em favor do estilo feérico, das vedetes, do show, era a "fase do deslumbramento" (VENEZIANO, 1991: 50). 
Salvyano de Paiva retrata aquele momento de forma mais pessimista:

A coerência crítica e estrutural cede vez a um amontoado de asnices, de esquetes caóticos, cortinas e quadros sem pé nem cabeça. A degenerescência do gênero, causada por um feixe de fatores díspares, simultâneos e crescentes, o aparecimento de substitutivos, tudo conduziu ao seu extermínio (PAIVA, 1991: 467).

Ainda sobre a nova forma da revista nos palcos cariocas, ao falar sobre o ano de 1944, em que é lançado Berlim na batucada, Paiva afirma:

Impunha-se cada vez mais o modelo feérico; gradativamente o humor inteligente entrava em recesso ou cedia lugar a bufoneria curta e grossa. Escasseavam os cômicos criativos, as atrizes capazes de reunir beleza física, talento vocal, desembaraço, versatilidade. Os bons escribas morriam ou se aposentavam; a renovação não ocorria pelo desestímulo (PAIVA, 1991: 497).

Deste modo, podemos estabelecer um paralelo em relação às hipóteses colocadas por Bernardet, quanto à Bela Época, para compreender o aparente receio de alguns filmes em utilizar o termo "revista" em sua divulgação. Do contrário, corriam o risco de ficarem associados a um gênero teatral que caminhava para uma forte descaracterização em relação ao que apresentara nas décadas anteriores.

Mais um sinal dessa preocupação é a nota publicitária do filme, sintomática desse aspecto de negação, que colocava: "Sua história é uma sucessão de episódios muito bem articulados que nos envolvem a atenção, empolgando-nos e nos oferece as mais fortes emoções e nos provoca as gargalhadas mais gostosas (A Manhã, 1944: 9).

Contudo, as características do teatro de revista brasileiro, que teve seu auge nas décadas de 1920 e 1930, permaneceriam, de forma ora mais ora menos visível, em várias comédias do período, inclusive influenciando, com seus quadros cômicos e atores célebres, as clássicas chanchadas da década de 1950.

\section{Referências Bibliográficas}

ANTUNES, Delson. Fora do sério: um panorama do teatro de revista no Brasil. Rio de Janeiro: Funarte, 2002.

ARAÚJO, Vicente de Paula. A Bela Época do cinema brasileiro. 2.ed. São Paulo: Perspectiva, 1985.

BARROS, Luiz de. Minhas memórias de cineasta. Rio de Janeiro: Artenova/ Embrafilme, 1978.

BERNARDET, Jean-Claude. Historiografia clássica do cinema brasileiro. São Paulo: Annablume, 1995.

CINÉDIA 75 ANOS. São Paulo: Centro Cultural Banco do Brasil, 2006.

COSTA, Fernando Morais da. O som no cinema brasileiro: revisão de uma importância indeferida. Rio de Janeiro: UFF, 2006. 268f. Tese (Doutorado em Comunicação) - Programa de Pós-Graduação em Comunicação, Universidade Federal Fluminense, Ripo de Janeiro, 2006.

FERREIRA, Suzana Cristina de Souza. Adhemar Gonzaga e a Cinédia: imagens de um país que dança. Belo Horizonte: UFMG, 2006. 193f. Tese (Doutorado em História) - Programa de Pós-Graduação em História, Universidade Federal de Minas Gerais, Belo Horizonte, 2006. 
FREIRE, Rafael de Luna. Carnaval, mistério e gangsters: o filme policial no Brasil (1915-1951). Niterói:UFF, 2011.504f. Tese (Doutorado em Comunicação)-Programa de Pós-Graduação em Comunicação, Imagem e Informação, Universidade Federal Fluminense, Niterói, 2011.

PAIVA, Salvyano Cavalcanti de. Viva o rebolado! : Vida e morte do teatro de revista brasileiro. Rio de Janeiro: Nova Fronteira, 1991.

SOUZA, José Inácio de Melo. Imagens do passado: São Paulo e Rio de Janeiro nos primórdios do cinema. São Paulo: Senac São Paulo, 2004.

VENEZIANO, Neyde. O teatro de revista no Brasil: dramaturgia e convenções. Campinas: Pontes: Editora da Universidade Estadual de Campinas, 1991.

\section{Periódicos}

A MANHÃ: Rio de Janeiro. Disponível em: <http://hemerotecadigital.bn.br/ manh\%C3\%A3/116408>.

A NOITE: Rio de Janeiro. Disponível em: <http://hemerotecadigital.bn.br/ noite/348970>.

DIÁRIO DA NOITE: Rio de Janeiro. Disponível em: <http://hemerotecadigital. bn.br/diario-da-noite/221961>.

\section{Páginas da internet}

Filmografia da Cinemateca Brasileira. Disponível em: $<$ http://www.cinemateca.gov. $\mathrm{br} /$ cgi-bin/wxis.exe/iah/?IsisScript=iah/iah.xis\&base =FILMOGRAFIA\&lang=p . 